\title{
Youth Professional Educational Games as a Condition for Young Teachers' Professional Identity Formation
}

\author{
Natalia F. Loginova* \\ Centre of Teachers' Professional Development Support \\ Krasnoyarsk Institution of Advanced Training \\ 19 Matrosov Str., Krasnoyarsk, 660000, Russia
}

Received 11.03.2015, received in revised form 22.06.2015, accepted 06.09.2015

Changes in the education system are accompanied by changes of a person's views on him/herself, his/her place in professional and social world. This leads to the difficulties with professional identity formation. The article presents the data showing the impact of young teachers' participation in youth professional educational games on professional identity formation.

Keywords: professional identity, young teachers.

DOI: 10.17516/1997-1370-2015-8-11-2505-2516.

Research area: pedagogy.

\section{Problematics}

Professional activity gives a person an opportunity to realize his/her potential, feel his/ her importance, understand life. To have a career means not only to be able to do something but also be included in the system of interpersonal interactions, feel a part of the professional community. It is well known that those who consider their work interesting and valuable for themselves are less subject to negative emotions and fell psychologically protected.

Recently the issues of a teacher's professional development, his/her professional identity formation are topical in the discussions of changes in the education system (V.A. Bolotov, A.G. Kasprzhak, K.G. Mitrofanov, et al.).
Identity and development in the course of professionalization are closely and complexly interwoven: on the one hand, professional identity is formed in the process of professional development; on the other hand, it is one of the important indicators of an individual professional's formation. "To survive in new dynamic socio-economic conditions, meet the competition, ensure prosperity and stability for the future the professional must be capable of constant development and analysis of his/her place in social and professional environment" (Ivanova 2008, p. 90).

Changes in Russian education result in a situation of instability. Teacher's career, his/ her mission, functions and ways of working are

(C) Siberian Federal University. All rights reserved

* Corresponding author E-mail address: loginova@kipk.ru 
cardinally changing. The teacher is no longer the main source of knowledge and should become an information flows coordinator, motivator and expert. He/she should cope with a child's (family's) educational needs providing an individual trajectory (programme) of development. This means that the teacher needs several scenarios of each class (lesson) development. The teacher's work should be focused on his/her students ability to apply knowledge in practice, to be not afraid to take responsibility, make decisions, evaluate their resources and look for the missing ones, learn new things and a lot more that is required by the Federal state educational standard. The difficulty of today's practice is that the existing system of pedagogical education does not prepare for it.

To describe a specific character of changes in the system of education it is worth while considering multi-professionalism, a tendency existingintheworld(A.P.Beliaeva,A.N.Leibovich, L.M. Mitina, A.Ia. Nain, P.G. Shchedrovitskii, et al.). This tendency is currently observed in the field of education. Whereas before now "the teacher" was the only qualification, modern teacher demonstrates "a diverse set of work types from a tutor to an education manager and a specialist in education law, from a new educational content developer to a specialist in educational projects implementation, from an educational tests developer and technologist to a specialist in the implementation of individual programs targeted at a child's special abilities" (K.G. Mitrofanov, P.A. Sergomanov, B.I. Hasan, et al., p. 142).

Thus, changes in the system of education are accompanied by changes of a person's views on him/herself, his/her place in the professional and social world. And this results in the difficulties of professional identity formation.

The scope of the article also comprises two problems, Krasnoyarsk Krai faces. These are 1) the problem of employment of graduates with pedagogical profession who got their degrees at the universities and colleges in Krasnoyarsk Krai; 2) the problem of keeping young teachers at school. On the average, the annual number of graduates with pedagogical education, who get in teaching at school, is only 35-40\% (Makovskaia). According to statistics, about $50 \%$ of young teachers leave the school after the first year of their work there (Mitrofanov 2012). This suggests that the existing forms of work with young teachers provide neither adaptation nor consolidation in the profession nor professional identity formation.

Thus, the problem of teachers' professional identity formation in general and young teachers' professional identity formation in particular is very urgent and raises the issue of how it should be achieved, that is what conditions should be created, what mechanisms should be activated, etc.

\section{Professional identity}

Professional identity is an autonomous concept with its own content. It is formed in the process of professional development and serves an indicator of the formation of a professional personality and his / her professionalization (Iu.P. Povarenkov, T.V. Mishchenko, et al.).

There are two points of view on the issue of place of professional identity in the structure of identity in general. The specificity of both points of view is reflected in Table 1 .

According to the first point of view, professional identity is understood as a subspecies of social identity, awareness of self as a member of professional community, understanding of one's own place in it, acceptance of the professional community's goals, norms and values, a professional's relevance to social demands, possibility to cope with challenges of life by means of a career (N.L. Ivanova, E.V. Koneva, E.P. Ermolaeva, D.N. Zavalishina, et al.). At that professional identity serves an internal schema 
Table 1. Approaches to the definitions of professional identity

\begin{tabular}{|c|c|}
\hline $\begin{array}{c}\text { Professional identity } \\
\text { as a part of social identity }\end{array}$ & $\begin{array}{l}\text { Professional identity } \\
\text { as a part of personal identity }\end{array}$ \\
\hline 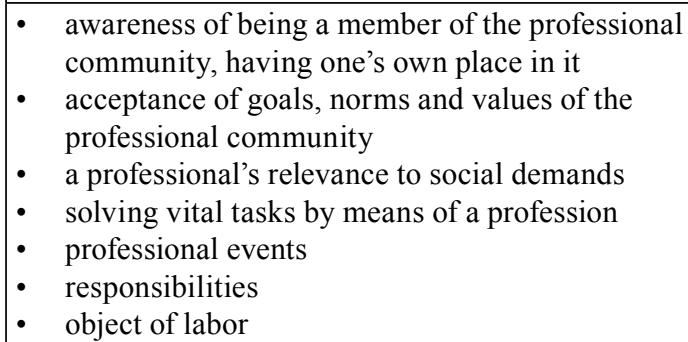 & $\begin{array}{l}\text { - } \text { evaluation of oneself as a professional } \\
\text { - } \text { evaling of being a professional } \\
\text { activity } \\
\text { - possibility of self-expression in the profession } \\
\text { - acceptance of values and norms characteristic of a } \\
\text { certain professional community } \\
\text { - unique (distinctive) characteristic features }\end{array}$ \\
\hline
\end{tabular}

reflecting a person's ideas of what personality he / she should be, what he / she should be able to do and how he / she should behave in the professional community for their successful self-realization and relevance in professional community (Kasprzhak 2013).

Cognitiveandvaluecomponentsareimportant at this approach. They reflect professionalism, views on one's own professionalism, possibility of one's change in a career, relevance to social order and expectations from a career ("Myself as a professional", "My place in a career", "I can", etc.).

Awareness of one's place in the professional community as a part of professional environment takes place along with the awareness of oneself as a professional. Awareness of oneself as a professional is thinking of oneself inside a certain circle of people, objects, events, and obligations. It is awareness of being a member of professional community, acceptance of its goals and values, relevance to social demands (Leibovich 1994).

According to the second point of view, professional identity is a component of personal identity development (M.M. Abdullaeva, T.M. Buiakas, M.V. Zakovorotnaia, E.F. Zeer, Iu.P. Povarenkov, L.B. Shneider, B. Abrahao, et al.). In this case professional identity is associated with axiological and conceptual attitudes. It makes it possible for a person to feel his / her identity as a professional, be aware of subjective attitude to his / her own professional activity, and realize his / her own uniqueness and opportunities for professional self-expression.

L.B. Schneider defines professional identity as a psychological category which refers to the awareness of one's belonging to a particular profession and a specific professional community. It is not only the awareness of identity with the professional community, but also its evaluation, psychological significance of being its member, shared professional feelings, specific mentality, feeling of one's professional competence, independence and self-efficacy, i.e. the experience of one's professional integrity and certainty (Shneider 2004).

According to Iu.P. Povarenkov, professional identity as a criterion of professional development indicates qualitative and quantitative features of a person's awareness of a) him/herself as a professional; b) a specific professional activity as a means of self-realization and meeting the needs; c) a system of values and norms characteristic of a certain professional community (Povarenkov 2006).

We believe that acceptance of one or another point of view confines a holistic consideration of the "professional identity" phenomenon. Therefore, we suggest considering professional 
identity as integration of personal and social identity in professional reality.

Professional identity is therefore proposed to be considered as a systemic, dynamic phenomenon forming a person's view on him/ herself as a professional (capable and solving a particular type of professional tasks), on goals and values shared by a professional group. It is accompanied with the feeling of belonging to a professional community, a professional community's recognition of a person as a professional, feeling of consistency of a professional community's ideas with current trends in professional activities that favour a personality's professional development (making plans regarding one's own career).

Despite a large number of works on the issue of professional identity the following questions remain unanswered. These are "how effective are the existing forms of work with young teachers for their professional identity formation?", "Is it possible to manage the process of young teachers' professional identity formation?"

This work is an attempt to answer the questions raised.

\section{The idea of research}

The basis for work was the research carried within the framework of the All-Russian research of effectiveness of the existing conditions of adaptation, consolidation and professional development of young teachers of the Russian Federation (State contract 08.N81.12.0088 dated October 24, 2014). Young teachers with teaching experience up to 3 years, school and municipal managers from all subjects of the Russian Federation took part in the research. Our research was based only on the data of young teachers of Krasnoyarsk Krai. We believe that due to the implementation of the "Youth professional educational games" project, which started in Krasnoyarsk Krai in 2011, the conditions for young teachers' consolidation and professional development are created.

Youth professional educational games (YPEG) is a system of professional competitions aimed at building a network of professional communities and young teachers' professional development in the krai. The content core of the games is mastering professional metasubject competencies by young teachers, the competencies being project thinking, critical thinking, research thinking, organizing the reflection, ability to work in team, leadership, effective communication, etc. that are specified in the new federal standards. YPEG participants make use of cases from their teaching practice in game. They give them as examples, cases for training. This allows regarding difficult practical situations as patterns, from different sides, playing them through, tackling them once again, and, thus, coping with the feelings that arose then, in class. It is worth while adding that all this takes place in the youth environment with its attractive aspects.

We assume that the formation of young teachers' professional identity will be more successful if:

- the activity is specially organized in the format of young teachers' professional competitions in the field of meta-subject competences;

- the reflection on own deficits, that become evident in the game, as well as their filling are organized;

- the informal space of professional and interpersonal communication of the participants and gaming professional movement is organized;

- the multi-level professional community included in the gaming professional movement is formed.

The research involved 236 persons: 135 young teachers of the krai, who took part in 
the All-Russian research but were not YPEG members, and 101 young teachers from among YPEG participants.

The method of research was questionnaire survey. The questionnaire contained questions of mostly closed type. Young teachers were asked to answer the questions about characteristic features of professional identity. These are the area of interest in working with children in their pedagogical activity, evaluation of professional well-being regarding various fields of pedagogical activity, recognition of their own professional deficiencies, description of the ability to work within the frames of basic curriculum, recognition of professional prospects for 3 years, views on professional development, etc.

\section{Some of the results}

Analyzing the respondents' answers, we have received a lot of interesting data. They cannot be presented in full and discussed in one article. Therefore, we suggest discussing the most interesting part of the research, from our point of view. The data will be presented and analyzed through the comparison of two groups of the respondents with and without YPEG participation experience.

Participation in YPEG allows young teachers to work at their professional skills, and namely to detect deficiencies and overcome them, develop certain professional skills, analyze and work through the difficult cases they had while teaching, etc. Therefore, we expected that YPEG participants would feel more confident, be aware of their professional deficiencies, be more equipped in their work with basic curriculum, and associate their future life with their career and their professional development with the development of their professional skills in various fields of pedagogical activity.

\section{Professional well-being}

Professional well-being was evaluated on the basis of the semantic differential principle, when the respondents are asked to rank their well-being in a polar set characteristic. The indicators of professional well-being were the following ones:

1 - a respondent's feeling of being professionally competent;

2 - a respondent's grounds of regarding him/ herself to be a teacher;

3 - the respondents' satisfaction with their pedagogical activity;

4 - a respondent's ability to cope with professional challenges;

5 - identity of the respondents' personal beliefs and values with a professional activity;

6 - a respondent's feeling of his/her own relevance in teaching community;

7 - a respondent's feeling of his/her colleagues' support;

8 - a respondent's feeling of being valued by the teaching staff;

9 - taking a respondent's opinion into consideration in making decisions in the teaching staff.

It turned out that young teachers who participated in YPEG positively evaluated their professional well-being according to all the characteristics while young teachers who did not participate in YPEG were significantly more negative in evaluation of their professional wellbeing according to all the characteristics. The significance of the differences was estimated through Fisher angular transformation (Fisher's ratio test $\varphi^{*}$ ). In the estimates of positive wellbeing the values of Fisher's ratio test $\varphi^{*}$ are $4,773-8,874$. They indicate the significance of differences at $p=0.01$. In the estimates of negative well-being the values of Fisher's ratio test $\varphi^{*}$ are $3,373-8,888$, suggesting the significance of differences at $\mathrm{p}=0.01$. These results are graphically presented in Fig. 1 and Fig. 2. 


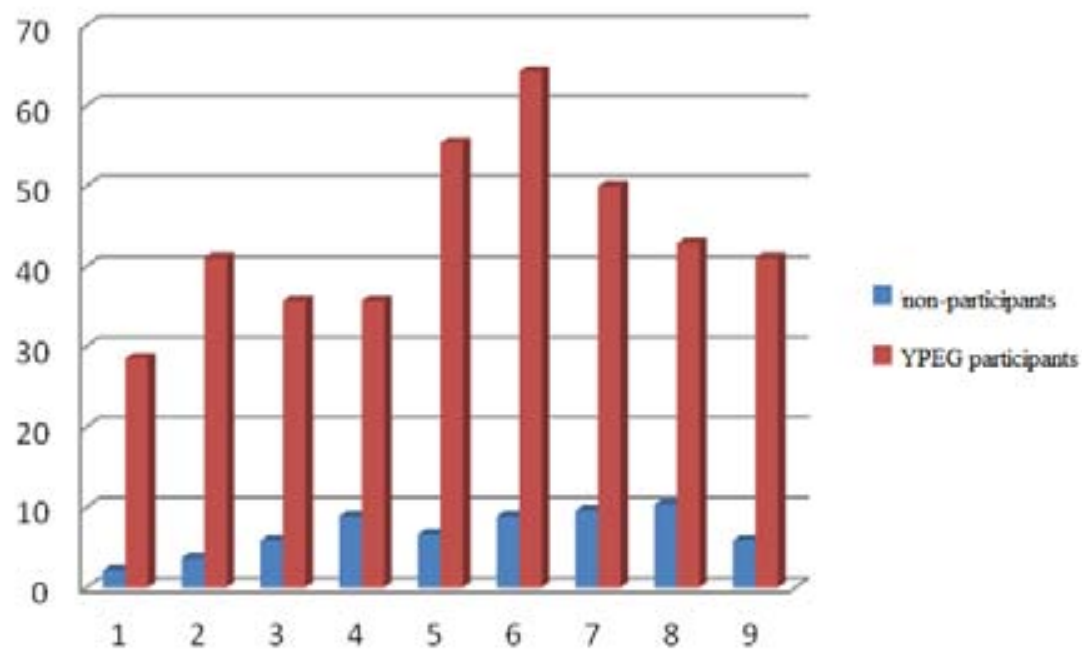

Fig. 1. Young teachers' positive evaluations of professional well-being

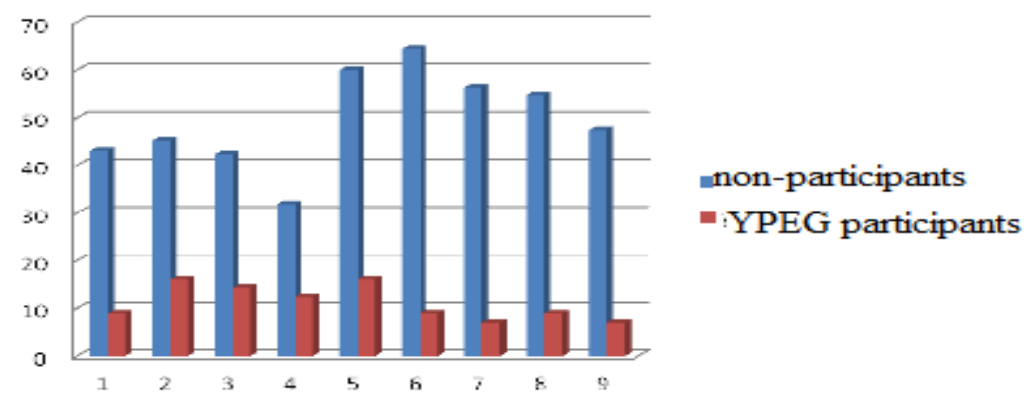

Fig. 2. Young teachers' negative evaluations of professional well-being

Thus, evaluating their professional wellbeing, young teachers with YPEG experience estimate all the parameters higher than young teachers without such an experience.

\section{Professional deficiencies}

The respondents were asked to choose three professional deficiencies they consider peculiar to them from the list of the given ones. Statistically significant differences between the groups of the respondents with and without YPEG experience were obtained regarding such deficiencies as the deficiency of meta-subject competencies and the deficiency of subject knowledge. The significance of the differences was estimated with Fisher angular transformation (Fisher's ratio test $\left.\varphi^{*}\right)$. The values of Fisher's ratio test $\varphi^{*}$ are 2,652 and 2,461, suggesting the significance of the differences at $p=0.01$. Thus, young teachers with YPEG experience much more often mention the deficiencies associated with subject and metasubject training, keeping them from effective solution of their tasks.

Despite statistical non-significance in selecting other professional deficiencies, the rank of priorities in defining professional deficiencies by both respondent groups (as per the number of choices) is a matter of interest. The respondents with YPEG experience rank the deficiency of meta-subject competencies to be the first (20.1 
$5 \%$ ), time constraints - the second (14.8\%), the deficiency of ability to plan one's activities and allocate resources - the third (12,1\%). The respondents without YPEG experience rank time constraints to be the first $(25.3 \%)$, lack of experience in working with children - the second (13\%), and lack of parents' understanding - the third (10\%).

Thus, YPEG participants mostly refer to the deficiencies of professional skills while the second group of the respondents refers to "external" things - lack of experience and parents' understanding, etc. This makes it possible to say that YPEG participants can define THEIR professional deficiencies whereas the respondents without such experience have difficulty with this.

\section{Interest in working with children}

Descriptions of a professional interest in working with children by the respondents of two groups do not differ significantly in statistic data. The respondents' answers distribution seems interesting regarding the choice of one or another option. The respondents of both groups rank the maintenance of children's initiative to be the first (22.6\% of YPEG participants' choices and $19.5 \%$ of non-participants' choices). In other cases the respondents' priorities disagree: YPEG participants consider working with children's issues $(21.4 \%)$ and setting educational objectives to the students and heart-to-heart talks (14.9\%) to be their professional interests. Young teachers with no experience of YPEG participation choose setting educational objectives to the students (18.4\%), too. They also chose spending time together in the process of education (excursions, walking tours, participation in cultural events) (13.4\%).

These data give grounds to assume that YPEG participants are more focused on the development of the students' meta-subject skills.

\section{Interaction with colleagues}

There are no statistically significant differences in the responses about the directions of cooperation with colleagues. However, priorities in the responses of both groups are of the research interest. All the respondents rank business relationships in discussing problematic issues, etc. with the colleagues to be the first $(80.7 \%$ of non-participants' responses, $75 \%$ of YPEG participants' responses). The rest responses differ. Young teachers, who are YPEG participants, first mention collaborative project activities with the colleagues (14.3\%) and only after that they refer to common leisure activities (7\%). The respondents without YPEG participation experience first mention common leisure activities $(11 \%)$ and then refer to collaborative projects ( $8 \%$ ). It is also worth mentioning that clubs and interpersonal friendship were dwelt upon only by YPEG participants.

This results in the conclusion that YPEG participants are more focused on productive collaboration with colleagues. They also have such a vital resource for well-being as friendly interpersonal relations with colleagues, helping them cope with all sorts of difficulties, recuperate, etc.

\section{Working with basic curriculum}

The analysis of the responses on the ability to work with basic curriculum has shown statistically significant differences: in contrast to the respondents with YPEG participation experience young teachers without such experience mention the ability to conduct a lesson on a particular topic in accordance with basic curriculum more often ( $62 \%$ vs $38 \%$ ). The value of Fisher's ratio test $\varphi^{*}$ is 3,38, suggesting the significance of differences at $p=0.01$. Young teachers with YPEG participation experience much more often mention the ability to modify basic curriculum taking into account their 


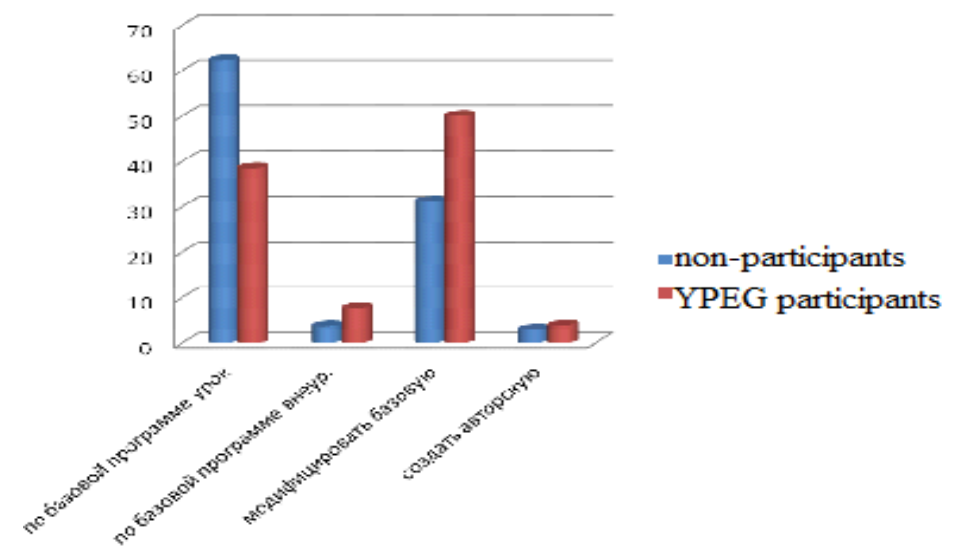

Fig. 3. Young teachers' ability to work with basic curriculum

students' age and personal characteristics $(50 \%$ vs $31 \%$ ). The value of the Fisher's ratio test $\varphi^{*}$ is 2,793 , suggesting the significance of differences at $\mathrm{p}=0.01$. These data are presented in Fig. 3 .

Thus, YPEG participants turn basic curriculum into a tool of solving THEIR pedagogical problems in working with children whereas young teachers without such experience work basing on the curriculum worked out FROM THE OUTSIDE.

\section{Understanding of prospects}

for the nearest three years

Fig. 4 presents the data under the analysis. Statistical analysis of the responses on the prospects for the next 3 years has revealed the difference in their understanding. Young teachers with YPEG participation experience dominate in choosing implementation of their own pedagogical projects, the value of the Fisher's ratio test $\varphi^{*}$ being 2,475 (the significance of differences is suggested at $p=0.01$ ). As for statistically significant differences in the responses on the directions of professional prospects, they were not revealed.

However, there is some specificity in the responses of both groups as per the number of choices of one or another option. The maximum number of choices by both responding groups refers to the improvement of professional skills in their field (24.5\% of non-participants' choices and $26 \%$ of participants' choices). After that YPEG participants mention the implementation of their own pedagogical projects $(13.7 \%)$ and mastering new skills and becoming good at new pedagogical activities (12.3\%). Young teachers without such experience rank studying at a higher level (higher education institutions, master courses) to be the second (11.5\%), mastering new skills and becoming good at new pedagogical activities (similar to YPEG participants) to be the third (10.8\%). Thus, participants with no YPEG experience focus on a "formal" aspect of their development (getting higher education) along with substantial profound progress in their professional development.

It is noteworthy that the respondents with YPEG experience do not view getting out of a career as their professional prospect whereas this response is given by young teachers without such experience (2.6\%). Young teachers without YPEG experience also mention the lack of plans, prospects (2.9\%).

These data suggest that YPEG participants mostly associate their professional prospects 


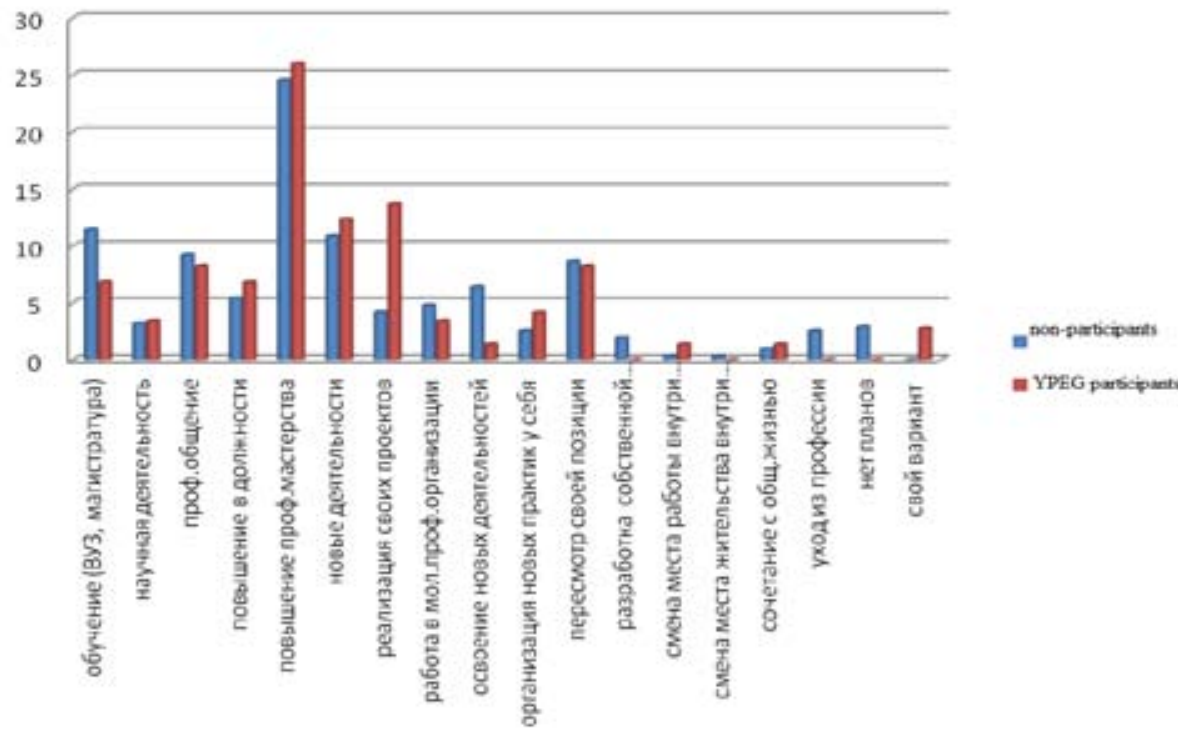

Fig. 4. Young teachers' views on their prospects for the nearest three years

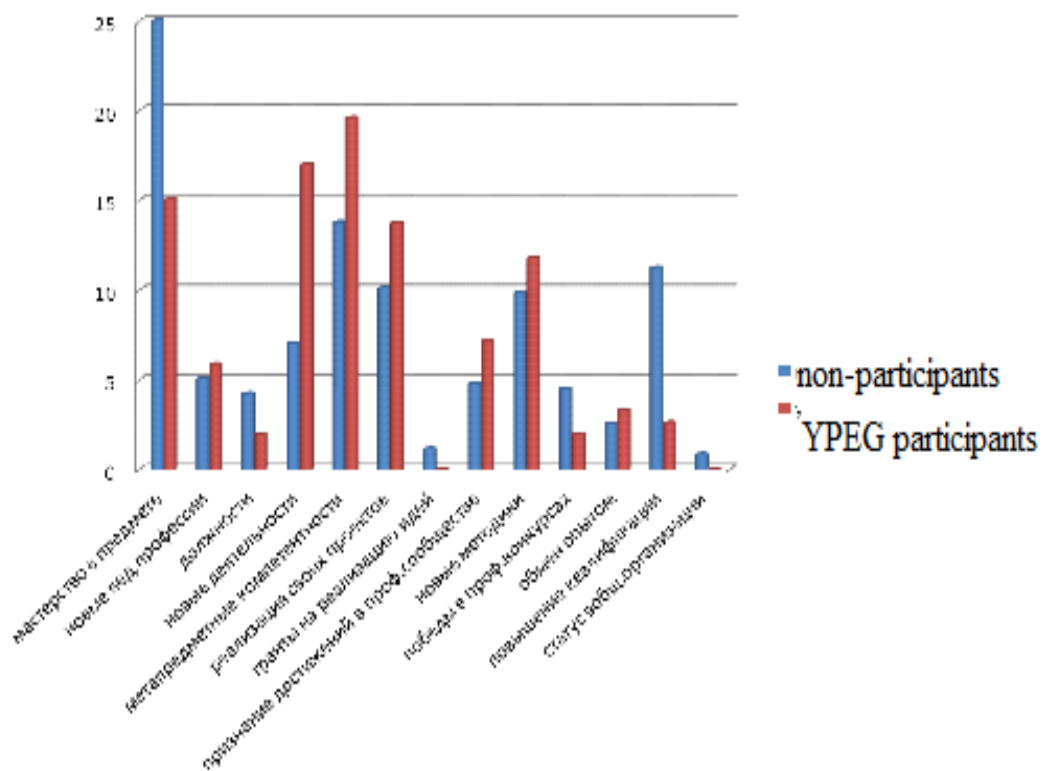

Fig. 5. Young teachers' views on their prospects for the nearest three years

with substantial profound progress, professional development.

\section{Views on professional development}

Fig. 5 presents the respondents' views on professional development. The diagrams make it clear that young teachers with YPEG experience consider professional development to be primarily the mastering meta-subject competencies (19. $6 \%$ ), mastering new activities through participation in projects, research groups, etc. (17 \%), and achieving 
excellence in the subject area (15\%). Young teachers with no YPEG experience consider professional development to be primarily the excellence in the subject area (25\%), mastering meta-subject competencies (13.8\%), and improvement of qualification grade (certification) $(11.2 \%)$.

Thus, we notice formal characteristics in non-participants' description of professional development. As for YPEG members, they consider only substantial characteristics related to professional excellence.

\section{Preliminary conclusions}

The mentioned above leads to the assumption that young teachers with YPEG participation experience feel more confident in their career than young teachers who are not involved in professional games movement. This means that young teachers' participation in youth professional educational games affects the success of young teachers' professional identity formation.

YPEG today is a number of events that are not particularly related to young teachers' practice at their school. There are precedents when this connection - of games and work - is built when a young teacher's participation in games significantly changes his / her teaching practice. This becomes the focus of school administration's attention but it is not a designed and formal practice.

The currently relevant task is to work out a system of work with young teachers, youth professional pedagogical games being its central element.

\section{References}

Abdullaeva M.M. (2004). Professional'naia identichnost' lichnosti: psikhosemanticheskii podkhod [Professional identity: psycho-semantic approach]. Psychological journal, 25 (2), 86-95.

Abrahao M.H. (2012). Menna Barreto Autobiographical research: Memory, time and narratives in the first person. European journal for Research on the Education and Learning of Adults, 3 (1), 29-41.

Beliaeva A.P. Integrativnaia teoriia i praktika mnogourovnevogo nepreryvnogo professional'nogo obrazovaniia [The integrative theory and practice of multilevel continuing vocational education]. St.Petersburg: Institute of vocational education of the Russian Academy of Education, 2002.

Bolotov V.A. (2012). Razmyshleniia o reforme pedagogicheskogo obrazovaniia [Rreflections on the reform of pedagogical education]. Educational policy journal, 5 (61), 8-14.

Buiakas T.M. (1997). Tsennostno-smyslovaia sfera professionala [Professional's alue-andsemantic sphere]. Mir psikhologii, 3, 10-18.

Ermolaeva E.P. (2005). Sotsial'nye funktsii i strategii realizatsii professional v sisteme "chelovekaprofessiia - obshchestvo" [Social functions and implementation of a professional's strategies in the "human - profession - society". Psikhologicheskii zhurnal, 4, 30-40.

Ivanova N.L. (2008). Professional'naia identichnost' v sotsial'no-psikhologicheskikh issledovaniiakh [Professional identity in social and psychological researches]. Voprosy psikhologii, 1, 89-100.

Ivanova N.L. Professional'naia identichnost' kak factor konkurentosposobnosti lichnosti v sovremennom biznese [Professional identity as a factor of an individual's competitiveness in modern business]. Available at: www.hse.ru/data/329/649/1233/ГУ-ВШЭ-доклад.doc.

Kasprzhak A.G. (2013). Institutsional'nye tupiki rossiiskoi sistemy podgotovki uchitelei [Institutional deadlocks of Russian teacher training]. Educational studies, 4, 261-280. 
Koneva E.V. Primenenie uchebnykh znanii v professional'noi deiatel'nosti na raznykh etapakh stanovleniia professionala [Application of academic knowledge in a professional activity at different stages of a professional's formation]. Ed. by A.V. Brushlinskii, A.V. Karpov. Moscow; Yaroslavl: DIApress, 2001, pp. 207-222.

Leibovich A.N. Struktura $i$ soderzhanie gosudarstvennogo standarta professional'nogo obrazovaniia [Structure and content of the state standard of professional education]. Moscow: Vysshaia shkola, 1994, 278 p.

Makovskaia S.I. Obrazovatel'naia politika v Krasnoiarskom krae-territorrii operezhaiushchego razvitiia. Doklad i. o. ministra obrazovaniia i nauki Krasnoiarskogo kraia na avgustovskom pedagogicheskom sovete [Education policy in Krasnoyarsk krai, the territory of advanced development. Report of the acting Minister of education and science of Krasnoyarsk Krai at the August teaching staff meeting]. Available at: www.krao.ru/rb-topic_t_969.htm 17.

Mitina L.M. Psikhologiia truda i professional'nogo razvitiia uchitelia [Psychology of teachers' work and professional development]. Moscow: Academiia, 2004, 320 p.

Mitrofanov K.G. Sovremennye instituty $i$ tekhnologii professionalizatsii uchitelia $v$ sisteme nepreryvnogo pedagogicheskogo obrazovaniia [Modern institutions and technologies of teachers' professionalization in the system of continuous pedagogical education]. Krasnoyarsk, 2012, $316 \mathrm{p}$.

Mitrofanov K.G., Sergomanov P.A., Hasan B.I. et al. Otsenka professional'nogo sostoianiia pedagogov dlia kraevoi programmy "Formirovanie kadrovogo potentsiala uchitel'stva Krasnoiarskogo kraia" [Evaluation of the teachers' professional status for the regional program "Formation of the potential of teaching resources in Krasnoyarsk krai". Available at: old.kipk.ru/files/fck/158/file/2010 Rezyume_k_zadaniyu_N_02.doc 21 .

Mitrofanov K.G., Vasil'eva N.P., Kozyreva E.Iu. Problemy professionalizatsii rabotnikov obrazovaniia. Vvedenie v problematiku [Problems of educators' professionalization. Introduction to problematics]. Pedagogika razvitiia: dvizhushchie sily i praktiki razvitiia: materialy 17 nauchnoprakticheskoi konferentsii, Krasnoyarsk, aprel' 2010 [Pedagogy of development: driving forces and development practice: Proceedings of 17 theoretical and practical conference "Pedagogy for development: driving forces and development practice", Krasnoyarsk, April 2010. Krasnoyarsk: KKIPK, 2011, pp. 128-143.

Nain A.Ia. Podgotovka kadrov v usloviiakh rynka [Personnel training under market conditions]. Cheliabinsk, 1995, $264 \mathrm{p}$.

Povarenkov Iu.P. (2006). Psikhologicheskoe soderzhanie professional'noi identichnosti [Psychological content of professional identity]. Siberian journal of psychology, 24, 53-58.

Shchedrovitskii P.G. Uzlovye problemy sovremennogo obshchestva i trebovaniia k starshei shkole [Key problems of modern society and requirements for high school]. Starshaia shkola kak vzroslaia zhizn': programmirovanie soderzhaniia obrazovaniia: Materialy seminara [Senior school as adult life: programming the content of education: Workshop materials]. Krasnoyarsk, 2000, pp. 4-12.

Shneider L.B. Professional'naia identichnost': teoriia, eksperiment, trening [Professional identity: theory, experiment, training]. Moscow: Publishing house of Moscow Psychological and Social Institute; Voronezh: Publishing house NPO “MODEK”, 2004, 600 p.

Vatashchak I.S. Vozmozhnosti professional'nogo razvitiia molodogo pedagoga [Opportunities of a young teacher's professional development]. Molodezh i nauka: sbornik materialov VIII Vserossiiskoi 
nauchno-tekhnicheskoi konferentsii studentov, aspirantov i molodykh uchenykh, posviashchennoi 155letiiu so dnia rozhdeniia K.E. Tsiolkovskogo [Youth and science: proceedings of VIII All-Russian scientific-and-technical conference of students, postgraduates and young scientists dedicated to the 155 anniversary of K.E. Tsiolkovsky's birth. Krasnoyarsk: Siberian Federal University, 2012, pp. 96100 .

Zakovorotnaia M.V. Identichnost' cheloveka. Sotsial'no-filisofskie aspekty [A person's identity. Social and philosophical aspects]. Available at: http://psy-dv.org/load/57-1-0-414 10.

Zavalishina D.N. Sposoby identifikatsii cheloveka s professiei [Methods of human's identification with the profession]. Psikhologiia sub'ekta professional'noi deiatel'nosti [Psychology of a subject of a professional activity]. Moscow-Yaroslavl: Yaroslavl State University, ed. by A.V. Karpov, 2001, pp. 104-128.

Zeer E.F. (2002). Strategii preodoleniia krizisov professional'nogo stanovleniia lichnosti pedagoga [Strategies of overcoming crises of teacher's personality professional formation]. Mir psikhologii, 4, 194-203.

\section{Молодежные профессиональные педагогические игры как условие формирования профессиональной идентичности молодых педагогов}

Н.Ф. Логинова Красноярский краевой институт повышения квалификации и переподготовки работников образования Россия, 660000, Красноярск, ул. Матросова, 19

\footnotetext{
Происходящие в системе образования изменения сопровождаются изменением представлений человека о себе, своем месте в профессиональном и соииальном мире, что приводит к тому, что появляются сложности с обретением профессиональной идентичности. В статье представлены данные о влиянии участия молодых педагогов в Молодежных профессиональных педагогических играх на становление их профессиональной идентичности.
}

Ключевые слова: профессиональная идентичность, молодые педагоги.

Научная спещиальность: 13.00.00 - педагогические науки. 